\title{
Global R\&D in the Aerospace and Defence Industry. Knowledge Creation with Local Firms in Host Countries
}

\section{I+D Global en la Industria Aeroespacial y de Defensa. Creación de Conocimiento con las Empresas Locales de los Países Anfitriones}

\author{
Javier López-Otero \\ Javier.lopez.otero@ui1.es@ https://orcid.org/0000-0002-6543-2926 \\ Universidad Isabel I. Calle Fernán González, 76. 09003 Burgos (España) \\ Renato Garcia \\ rcgarcia@unicamp.br @ https://orcid.org/0000-0001-9739-1658 \\ Institute of Economics, University of Campinas. \\ Calle Pythagoras. 353. 13083-857 Campinas (Brazil)
}

\section{INFO ARTÍCULO}

Enviado: 30-12-2019

Revisado: 24-01-2020

Aceptado: 28-01-2020

\section{KEYWORDS}

Aerospace Industry

Offshore R\&D

University Knowledge Spillovers

Military Knowledge Spillovers

Innovation

\section{PALABRAS CLAVE}

Industria Aeroespacial

I+D Offshore

Spillovers De Conocimiento de las Universidades

Spillovers de Conocimiento Militar

Innovación

\begin{abstract}
In this paper we examine the impact of three host country $(\mathrm{HC})$ factors like spillovers from Aerospace R\&D, Military R\&D and University research on a sample of aerospace firms for knowledge creation and collaboration with local HCs inventors. Data sources include a sample of 874 international plants of aerospace companies, which was split into OEM firms (Original Equipment Manufacturers) and top specialized supplier firms (TIER), and information from the HCs. The results showed the existence of knowledge spillovers from aerospace R\&D and research institutions produced in HCs. The OEM group is more efficient than the TIER group in appropriating aerospace R\&D. On the contrary, TIER group is more globalized and their knowledge is more based on their own expertise than on in-house R\&D. Foreign aerospace firms benefit specially from research institutions' knowledge spillovers produced in related fields to the aerospace industry.
\end{abstract}

\section{RESUMEN}

En este artículo se analiza el impacto de tres factores del país anfitrión (HC), como los knowledge spillovers procedentes de la I+D aeroespacial, la I+D militar y la investigación de Universidades en la capacidad de creación y colaboración con inventores del $\mathrm{HC}$ de una muestra de empresas aeroespaciales que incluye OEM (fabricantes de equipos originales) y proveedores especializados (TIER). Para ello se emplea una muestra de 874 plantas internacionales de compañías aeroespaciales con información sobre los respectivos HC. Los resultados evidenciaron la existencia de spillovers de conocimiento producidos en los HC con origen en la I+D aeroespacial y las instituciones de investigación. El grupo OEM es más eficiente que TIER en la apropiación de I+D aeroespacial. El grupo TIER está más globalizado y su conocimiento se basa más en su propia experiencia que en la I+D interna. Las empresas aeroespaciales extranjeras se benefician especialmente de los spillovers de conocimiento de las instituciones de investigación producidos en campos relacionados con la industria aeroespacial. 


\section{INTRODUCTION}

In recent years, firm's R\&D activities have experienced a significative geographical expansion due to the impact of globalization, and particularly, the development of IT and transport technologies (Lucendo-Monedero, A. L., Ruiz-Rodríguez, F., \& González-Relaño, R., 2019). In this sense, there is a growing concern of firms with the existence of international knowledge spillovers which could be appropriated by foreign firms in order to increase their productivity of knowledge (Thomson, 2013; Dunning and Lundan, 2009; Guimon, 2008; Florida,1996; Florida,1996).

Since the mid-twentieth century, companies have been involved in a growing industrial disinvestment in their countries of origin and a corresponding offshoring of parts of the production process to other locations, but nevertheless maintaining the design and R\&D centers in the country of origin. Subsequently, these activities also started to be globalized in many sectors and, thus, numerous MNCs (Multinational Corporations) began to undertake R\&D outside their country of origin. Moreover, in recent years, there has been a change in the relationship between Headquarters (HQ) and international plants in host countries (HCs), where the latter have acquired a greater degree of autonomy to develop their own competencies (Massini, and Murtha, 2009; Cantwell, and Piscitello, 2005; Andersson, Forsgren, and Holm, 2001).

Thus, aerospace production has gone from being an industry located in very few countries to one having a high degree of globalization (Butterworth-Hayes, 2007), evolving from a heavy concentration in Europe and the United States towards an increasingly global distribution of production, in which emerging powers (Brazil, Russia, India and China) are acquiring significant weight (McGuire, 2014; ECORYS, 2009; Moser, Heiko and Gnatsy, 2010; Polak and Belmondo, 2006; Parr, 2006). The reason behind is the growing presence of related industries like automotive and shipbuilding in emerging countries, as well as a growing military expenditure, big local markets for civil transport, and a successful direction from local institutions in the aforementioned countries. It is, therefore, a sector with a production chain that is constantly becoming more complex, and more fragmented from a geographical point of view (McGuire, 2014; ECORYS, 2009; Hollanders, Cruysen and Vertesy, 2008), although this degree of dispersion varies depending on whether we are dealing with the civil or military sub-sector (Mowery, 2012; Healey, 1999). However, the geographical expansion of the production process in the aerospace industry is followed by an expansion of R\&D activity. Thus, aerospace firms are making R\&D efforts in other countries in order to take advantage of their technological production (Liu and Chen, 2012; Zedtwitz and Gassmann, 2002), after the incorporation of a technological center following a recent merger or acquisition (Boutellier, Gassmann, and Von Zedtwitz, 2013; Zedtwitz and Gassmann, 2002), or to comply with the obligation offset imposed by HCs in exchange for opening their market (Wessner, 1999).

Moreover, although there is a broad conceptual framework that addresses the causes behind other countries' R\&D offshoring (knowledge sourcing) processes through technological collaborations, very few works study the specific case of aerospace activity. Thus, this paper analyzes knowledge appropriation, adapting the theories that have studied knowledge spillovers and R\&D offshoring to the particular characteristics of the aerospace and defense industry. In particular, the processes of R\&D offshoring to host countries (HC) are addressed, highlighting the factors that favor the appropriation of HC knowledge spillovers. Likewise, it is considered that there is a gap in the scientific literature on aerospace knowledge spillovers as most of the studies on this phenomenon are based on samples of firms that belong to a single country.

Therefore, the main aim of this research is to examine the appropriation of aerospace international knowledge spillovers by aerospace firms and produced in HC.

\section{CONCEPTUAL FRAMEWORK}

The internationalization of the R\&D of MNCs is a phenomenon that is receiving great attention (Awate, Larsen and Mudambi, 2015 ; Teece, 2014; Boutellier, Gassmann, and Von Zedtwitz, 2013), especially in the wake of the growing trend towards the dispersion of activities with high added value (D'Agostino, Laursen and 
Santangelo, 2012; Zedtwitz and Gassmann, 2002), in their analysis of processes of R\&D offshoring to host countries, discovered that an important part of the R\&D internationalization process is due to globalization itself, and specifically to the merger and acquisition of companies. However, most new R\&D centers were created with the aim of providing greater support to international markets, and to have better access to local science and technology (UNCTAD, 2005). Other works Liu and Chen, (2012) warn of the shift from a business policy of R\&D offshoring towards knowledge sourcing, according to which companies are transforming their subsidiaries from a competence-exploitation function to a competence-creating one (Ha and Giroud, 2015).

Hence, the difference in R\&D productivity between territories provides a clear incentive to locate activities outside the country of origin (Coe, David and Elthanan Helpman, 1994). There are certain features that are more attractive than others for carrying out R\&D activities in a foreign country. In this respect, various empirical studies have highlighted the skill levels of human resources (Florida, 1996), the existence of an advanced research infrastructure, the dynamism of the regional innovation system (Guimon, 2008; JordáBorrell, R., Ruiz-Rodríguez, F. and González-Relaño, R.,2015), or the culture of the home and host country (Morschett, Schramm-Klein, and Swoboda 2010), and the country risk (López and Vidal 2010).

On the other hand, the aerospace industry (AI) has marked traits of business concentration and spatial dispersion (ECORYS, 2009), as well as a very hierarchical structure. The main causes of the first characteristics are the need for continuous interaction between suppliers and clients which makes proximity of location necessary (Niosi and Zhegu, 2010); and the scarcity of competitors, basically due to the fact that financial barriers to entering the sector are very high (PWC, 2014). Nevertheless, this situation does not preclude strong competition among production companies, especially now that some firms from developing countries have started participating.

Moreover, the AI is very hierarchical (Niosi and Zhegu 2005), and specifically it consists of tiers of firms that are organized in a pyramidal fashion. Thus, at the second level are the Tier 1 firms that are involved in activities such as propulsion, communication systems and landing systems, examples of which could be GE, UTC, Rolls Royce, Thales, etc. Both the OEMs and the Tier 1 firms are very large in terms of turnover and staff. Lastly, there are Tier 2 and Tier 3, which consists by usually small or medium-sized firms that develop sub-packages for the main contractors.

The rising costs of research and development force companies to share costs and responsibilities, and thus to specialize in specific fields of AI (Niosi and Zhegu 2010; López-Otero,J, Contreras-Cabrera, G and Jordá-Borrell, R, 2015; Lopez-Otero, J., 2014). A technological alliance necessarily involves the partial or total transfer of knowledge to the collaborating company, which may give rise to the latter incorporating the acquired knowledge into its skills base. In fact, this collaboration is the main source of knowledge acquisition after in-house R\&D (Niosi and Zhegu 2005)

Undertaking R\&D outside the country of origin is a recent phenomenon in the AI, and it is mainly driven by two factors, one of these being offset agreements, which were defined by Healey (1999). These involve technology transfer via R\&D centers in the country of destination, technical assistance, or a joint venture (Crabb, 1989). After signing this agreement, companies regulate the technology transfer via the offset, to ensure that it does not lead to the creation of a competitor. Moreover, it is also supervised by governments to prevent the transfer of technology that could jeopardize the security of the country of origin (Healey, 1999).

The second driver consists in the need of OEMs to find specialized partners in specific fields of aeronautics, and which will have the category of top suppliers or Tier 1. This new organization arises from the increasing technological diversity occurring in the sector. Hence, the OEMs share R\&D costs with Tier 1 firms in programs that have a significant risk of failure, and consequently the costs of a hypothetical failure are not only borne by the OEM but by both. Therefore, this collaboration between a small number of OEMs scattered among a few countries and a slightly larger number of Tier 1 suppliers requires increasing international cooperation in R\&D, and ultimately shifting R\&D activities to a global setting (Lopez-Otero, J, Contreras-Cabrera, G. and Jordá-Borrell, R., 2015; ECORYS, 2009). All of this leads to a growing interdependence between the firms that carry out $R \& D$, apparent in the progressive increase in the percentage of international collaborations (PWC, 2014; ECORYS, 2009; Eriksson, 2000). 


\section{HYPOTHESIS DEVELOPMENT}

After an exhaustive bibliographic review of international R\&D activity in the AI, the following hypotheses are proposed.

It has been seen in the theoretical section that firms are capable of taking advantage of knowledge spillovers from the local or regional environment (Audretsch and Lehmann, 2005; Audretsch and Feldman, 2003; Audretsch, and Feldman, 1996). However, the globalization of production processes (Niosi, 2012; ECORYS, 2009) shows that the appropriation of knowledge spillovers is not strictly a local, regional or national phenomenon, but that it is also international (Stembridge, 2007). This is due to the fact that the forming of temporary or permanent relationships between units of companies that enable frequent interaction, and thus tacit knowledge transfer, is becoming more and more common thanks to ICTs, the transport revolution and the location of international plants in HCs. In this way, tacit knowledge' "spatial stickiness" may be overcome (Rychen and Zimmermann, 2008; Almeida and Phene, 2004; Gertler , 2003).

It can therefore be posited that companies may benefit from aerospace knowledge spillovers coming not only from their national environment but also from the international sphere. Furthermore, it is reasonable to assume that the AI, as it has great technological transversality, may benefit not only from knowledge spillovers from the aerospace industry itself, but also from other related industries (Guffarth and Barber, 2013), due to its cognitive proximity (Nooteboom et al., 2007). Thus, following the arguments put forward, the following hypotheses are presented:

- H1: The R\&D effort of firms and the aerospace R\&D effort of the HC has a positive impact on knowledge production via technological alliances.

- H2: The R\&D effort of firms and the R\&D effort in all industries of the HC has a positive impact on knowledge production via technological alliances.

Many studies have proved the existence of knowledge spillovers from universities (Fontana, Geuna, and Matt, 2006; Audretsch, Lehmann and Warning, 2004; Jaffe, Trajtenberg and Henderson 1993; Jaffe, 1989). However, several empirical studies on the AI have minimized the role of universities as producers of spillovers to the AI (McAdam et al. 2008, O'Hare and Moffatt, 2008), or even discounted it (Mowery, 2012; Niosi, 2005), due to the fact that direct cooperation or the number of collaborative projects is quite limited. However, the following hypotheses argue that knowledge spillovers may exist via the literary production of universities, to a lesser extent through past collaborations, and even from the work of university graduates. Likewise, most of the analyses of the role of universities in firms have been conducted on a local geographic scale, studying the influence of knowledge spillovers from university and research institutions in the same country or district (PWC, 2014; Liu and Chen, 2012; McAdam et al., 2008; Hollanders Cruysen and Vertesy, 2008).

These hypotheses aim to analyze the appropriation of knowledge spillovers from universities and research institutions in the HC. The parameters used as a proxy for assessing the appropriation of knowledge spillovers are the perceived quality of public and private research institutions by local corporations. A positive assessment implies a good relationship between the production apparatus and these research centers. Likewise, a good assessment of this relationship indicates satisfaction with the preparation of university graduates and academic specialists, and with their respective academic production. However, in order to analyze scientific production of HCs in the aerospace field more explicitly, a second hypothesis has been included on the production and specialization of the HC's research institutions in this scientific field. Scientific production and specialization in this field denote a larger number of academics specialized in the AI in a given HC (Broekel and Boschma, 2011). It is also reasonable to assume that AI may benefit from scientific production from sectors related to AI due to its aforementioned technological transversality, (Niosi, 2005). Hence, in line with this argument, the following hypotheses were proposed:

- H3. The quality of the institutions of the HC has a positive impact on the acquisition of knowledge spillovers generated in the $H C$.

- H4.1 The production of high impact aerospace scientific literature in the HC has a positive effect on knowledge creation in firms. 
- H4.2 The production of high impact scientific literature related to engineering in the HC has a positive effect on knowledge creation in firms.

Different studies have analyzed technology transfer from the defense sector to the civil sector (Mowery, 2012; Mian, 2011). The AI has strategic importance in a country's security, and thus there are frequently restrictions on the transfer of cutting-edge knowledge. Despite this, some studies have confirmed the existence of transfer of technological knowledge from the military to the civil sector (Mowery, 2012; Healey, 1999). However, most of these studies have considered the country of origin of the firms as the geographic framework, and the possible existence of aerospace knowledge spillovers from defense to the international civil sector had not been studied until now.

There is currently a growing number of military projects, especially in Europe and the United States, that are starting to decentralize parts of the production process to international suppliers, which in most cases are part of offset negotiations (Malm, 2016; Crabb, 1989). The location of an assembly plant in a HC entails the combination of different technologies and therefore requires a great technological effort. Consequently, these plants usually locate R\&D activities as support for the success of assembly and product testing CSO2011-26125, (2014). Research project and CSO2015-67662-P (2017). Research Project).

Hence, in line with the reasons set out, the following research hypotheses are presented:

- H5: The military R\&D undertaken in HCs has a positive relationship with knowledge production in firms.

- H6: The location of assembly plants for military projects in HCs is positively related to knowledge production in firms.

Finally, a set of control variables is included, which are the R\&D intensity of the firm, which is expected to have a positive sign. Likewise, the geopolitical proximity (Geopol) factor is introduced into the model and this is also considered to have a positive impact, that is, the firms whose home and host countries belong to the same geopolitical bloc should be more likely to create knowledge via technological alliances. Moreover, the size of the firm (Size) factor is also introduced, which is also thought to have a positive impact. Finally, the technological capability (TC) of firms factor is introduced, which is considered to have a positive impact on knowledge production.

Finally, given the different nature of OEMs and tier firms explained in the previous section, both processes are analyzed separately due to the different nature of OEMs and tier firms, explained in the previous section. By using this strategy, we aim to prevent the homogeneous processing of the information results in the different synergies of one group and the other leading to erratic conclusions. Furthermore, studying both sets separately gives a more complete picture of the processes of appropriation of knowledge spillovers.

\section{DATA}

Testing the hypotheses required the prior development of a database that included information on 65 firms in the aerospace sector selected from the list drawn up by PWC (PWC, 2016), which includes the main AI corporations by revenue for 2016. Information was then introduced on each international plant of each company in the sample according to the host country where they are located ${ }^{1}$. Subsequently, explanatory variables for the country factors related to the proposed hypotheses $(\mathrm{H} 1-\mathrm{H} 6)$ were introduced, using the OECD database and the Stockholm International Peace Research Institute (SIPRI, 2012) as sources, and also a set of control variables related to the innovative characteristics of the firms in the sample on the basis of the EU Industrial R\&D Investment Scoreboard 2012. Moreover, in line with the analysis intended in this research, only the strictly international knowledge spillovers were studied, and thus all the HQ plants and their corresponding geographic information were excluded from this sample.

1. The unit of spatial observation considered in the sample is the $\mathrm{HC}$ of international plants, regardless of the number of plants that each country may host. A company that has several plants in a country will therefore just count as one in this HC. 
Although it is possible that the publication of patents does not provide a totally accurate picture of the knowledge created in firms, especially in activities related to defense programs since knowledge embbeded in military weapons critical to the national security are kept in secret and not patented for fear they might be appropriated by rival nations or even enemies. Nonetheless, this variable still it is the most objective indicator available (Hollanders, Cruysen and Vertesy, 2008; Griliches, 1990).

On the other hand, no sectoral restriction of the patents produced by this set of firms has been imposed, in view of the multi-technological nature of aerospace firms. In this respect, some authors consider aerospace R\&D is not exclusively confined to the aerospace or defense sectors (Niosi, 2012) but also encompasses technologies from other industries.

A database of 874 international plants corresponding to a sample of 65 firms was built. However, as stated before, in order to test hypothesis on both groups firms (OEM and TIER) this database was split into two databases with 159 and 701 observations. These plants are located in 52 countries, distributed over the five continents, and which fall within the main geopolitical blocs (table 1).

Table 1. Distribution of the plants of the sample according to geographical area.

\begin{tabular}{|l|c|c|c|}
\hline \multicolumn{1}{|c|}{ Geopolitical bloc } & Firm's home country & OEM plants & TIER plants \\
\hline Europe & 18 & 61 & 297 \\
\hline Middle East, North Africa, and Pakistan & 1 & 23 & 81 \\
\hline Latin America and the Caribbean & 37 & 11 & 71 \\
\hline Southeast Asia & 2 & 20 & 71 \\
\hline East Asia & 4 & 18 & 59 \\
\hline North America & 1 & 10 & 53 \\
\hline South Asia & 1 & 7 & 34 \\
\hline Oceania & 0 & 5 & 26 \\
\hline Eurasia & 1 & 3 & 16 \\
\hline Sub-Saharan Africa & 0 & 1 & 7 \\
\hline Total & 65 & 159 & 715 \\
\hline
\end{tabular}

Source: Authors

Additionally, some in-depth interviews were conducted at 2 OEMs and 2 tier firms of the sample in order to confirm certain results obtained in the study in the area of R\&D offshoring CSO2011-26125 (2014) and CSO2015-67662-P (2017).

\section{METHOD AND MODEL}

The statistical modeling of the phenomenon to be analyzed, production of patents, in collaboration with firms from the HCs where international plants exist, means that in a large number of cases, (that is, HCs), there will be no collaboration and, consequently, the dependent variable will have a high number of zeros. This characteristic, along with the fact that it is a count variable, made it appropriate to use the Poisson Regression as estimation method. However, there tends to be an overdispersion of data in a large number of cases and, as a result, an overestimation of the variables is generated. Thus, after detecting the existence of overdispersion, the negative binomial regression method was used (Audretsch and Lehmann, 2005). 
Likewise, on considering that the number of zeros is very high, it is appropriate to apply the zero-inflated negative binomial regression as estimation method. The dependent variable has a lot of zeros, indicating that there are many countries where one of the firm's plants is located but with which no technological relationship is established because there is no innovative activity. A distinction, therefore, should be made between real zeros and false zeros. The former occur when there are capabilities to produce a patent in the observed country but nevertheless the observed value is 0 . The latter, meanwhile, are found in countries where it is highly unlikely that a patent is registered as these countries do not have the basic capabilities needed to innovate. Hence, the ZINB model performs a double analysis, that is, a regression model for count data and a logit model to distinguish the real zeros from the false (Krämer, Kretzschmar and Krickeberg, 2010). There are precedents for the use of this model in similar studies, such as that undertaken by Lee, et al. (2007).

The independent variables introduced in the model in order to demonstrate the research hypotheses were the following:

- LnRDintra: Total aerospace R\&D investment in the HC, in USD billions, for the year 2012 and in natural logarithmic form.

- LnRDextra: total R\&D investment in the HC, in USD billions, for the year 2012 and in natural logarithmic form

- QI: Quality of scientific research institutions on the Likert scale (1-7) for the year 2012

- SCAERO. Number of research papers published in the aerospace field by authors from the HC, for the years 2007 to 2012 and in natural logarithmic form.

- ScExtra. Number of research papers published in the engineering field by authors from the HC, for the years 2007 to 2012 and in natural logarithmic form.

- LnMR\&D: Investment in military R\&D in the HC, in USD billions, for the year 2012 and in natural logarithmic form.

- MP: Existence of an assembly plant of a military project located in the HC 1, 0 otherwise (dummy variable) (Corporate information).

The control variables:

- Geopol: The firm's home and host countries belong to the same political bloc 1, 0 otherwise (dummy variable), (possible blocs are NATO and NATO allies, ASEAN and China, UNASUR, Arab league, and INDIA)

- RDINTENSITY: Firm's R\&D investment as a percentage of revenue for the year 2012

- Size: Revenues of companies for the year 2012, in billions USD and in natural logarithmic form.

- LnTC: Number of patents in the six previous years (from 2007 to 2011) in natural logarithmic form

Some variables were transformed by the natural logarithm in order to obtain greater precision in the model due to the great dispersion of the data of the variables related to the HC's investment in R\&D, and those related to the size of companies due to their great variability. Finally, descriptive statistics related to OEM and TIER datasets are provided in annexes 5 and 6.

\section{RESULTS}

The analysis and comparation of the two groups of firms (OEM and TIER) are shown below table 2 reveals notable contrast between the sets of OEMs and Tier 1 firms. On the one hand, it can be seen that the OEMs have lower knowledge productivity, as each company produces around half the patents of the Tier 1 suppliers (column 3). On the other hand, given that the number of suppliers is higher than the number of OEMs, knowledge production in this sector is led to a large extent by supplier firms. Moreover, this table shows that the supplier firms establish most of the international collaborations with the HC entities (column 2), an aspect emphasized by the fact that the set of supplier firms is far larger than the set of integrators. However, the average trend of one set and another (column 4) is clear, the supplier firms generate $25 \%$ of knowledge via technological alliances with $\mathrm{HC}$ corporations, while the OEMs participate in a notably smaller percentage of technological collaborations. 
Table 2. Descriptive statistics on R\&D alliances by type of firm.

\begin{tabular}{|l|c|c|c|c|}
\hline $\begin{array}{c}\text { Type of } \\
\text { firm }\end{array}$ & $\begin{array}{c}\text { Distribution of total } \\
\text { patent production by } \\
\text { type of firm }\end{array}$ & $\begin{array}{c}\text { Distribution of interna- } \\
\text { tional R\&D alliances by } \\
\text { type of firm }\end{array}$ & $\begin{array}{c}\text { Average } \\
\text { R\&D alliances by type } \\
\text { of firm }\end{array}$ & $\begin{array}{c}\text { Share of R\&D inter- } \\
\text { national alliances in } \\
\text { relation to total firm's } \\
\text { R\&D alliances by type } \\
\text { of firm }\end{array}$ \\
\hline OEM & $31,98 \%$ & $13,52 \%$ & 180,20 & $18,3 \%$ \\
\hline TIER & $68,02 \%$ & $86,48 \%$ & 250,67 & $26,1 \%$ \\
\hline Total & $100,00 \%$ & $100,00 \%$ & 238,08 & 43 \\
\hline
\end{tabular}

Source: Authors

After having made the estimate, the analyses corresponding to the appropriation of knowledge by OEMs (table 3) and suppliers (table 4) are presented. The study of each set involved a double analysis. On the one hand, a double estimate of each hypothesis was made using negative binomial (NB) and zero-inflated negative binomial (ZINB). On the other hand, the control variables and the set of these variables were studied separately in order to analyze the increase resulting from the introduction of the independent variables.

For NB and ZNIB, estimates are outside the brakets, and standard errors are given inside. The asterisks, $*, * *$, and $* * *$ indicate significance at the $10 \%, 5 \%$, and $1 \%$ level, respectively.

Models 1 and 2 coincide in highlighting the R\&D intensity and Geopol variables in the set of control variables which, as expected, have a positive sign and they also have a high significance, especially the Geopol variable. Likewise, comparison between the log-likelihood tests indicates a notable increase with respect to the base model, with an increase of $\Delta 20.87$ and $\Delta 26.19$ respectively between models 1 and 3 , and 2 and 4 . This trend among the four models is also seen in the pseudo-r parameter.

Therefore, with respect to the first set of hypotheses, models 3 and 4 support $\mathrm{H} 1$, that is, the combination of competencies via technological alliances with HC firms; since it is sensitive to aerospace R\&D expenditure incurred in the HC. On the contrary, $\mathrm{H} 2$ was rejected in the model 4, and it was significant in model 3 with an unexpected negative sign. This is a contradictory result, nonetheless parameters as loglik, vuong test, or McFadden $r 2$ suggest that model 4 is more reliable, thus it could be considered the influence of spillovers from other industries apart from aerospace is weak.

In relation to the analysis of the set of hypotheses on the appropriation of spillovers from research institutions in the $\mathrm{HC}(\mathrm{H} 3, \mathrm{H} 4.1$ and $\mathrm{H} 4.2)$, it can be seen that only $\mathrm{H} 4.2$ was significant. Therefore, it can be affirmed that the HC's research institutions have an impact on the generation of technological alliances when there is a significative production of scientific knowledge in fields of engineering related to AI.

When the pair of hypotheses that analyzes the existence of spillovers from the military industry is studied, it can also be seen that $\mathrm{H} 5$ and $\mathrm{H} 6$ are not significant. Thus, the OEM set do not incorporate research conducted in the defense field into the knowledge creation procedure.

As for the control variables, it is noteworthy that, as in models 1 and 2, the Geopol variable has a positive sign and strong significance, as expected. This result implies that for the OEMs' plants the likelihood of combining and appropriating knowledge in the $\mathrm{HC}$ depends to a large extent on the geographic proximity between the OEM's country of origin and the HC. It is also worth mentioning that, as in models 1 and 2, the R\&D intensity variable has a positive sign and also shows notable significance, again as would be expected. Hence the production and combination of knowledge with $\mathrm{HC}$ firms depends on the sampled firms' effort in R\&D intensity.

For NB and ZNIB, estimates are outside the brakets, and standard errors are given inside. The asterisks, $*, * *$, and $* * *$ indicate significance at the $10 \%, 5 \%$, and $1 \%$ level, respectively.

The results of the estimates for the set of Tier 1 and Tier 2 suppliers are shown in Table 4 . As in the previous estimate, models 5 and 6 represent the base model that only includes the control variables. Thus, both of these models coincide in highlighting the importance of TC and Geopol variables, which have the expected 
Table 3. OEMs' estimation.

\begin{tabular}{|c|c|c|c|c|c|c|c|}
\hline Hypothesis & Variable & NB (1) & ZINB (2) & ZINB (2) & NB (3) & ZINB (4) & ZINB (4) \\
\hline & (Intercept) & $\begin{array}{c}-7.379 * \star \\
(3.369)\end{array}$ & $\begin{array}{l}-0.623 \\
(3.688)\end{array}$ & $\begin{array}{c}26.63 * \star \\
(7.791)\end{array}$ & $\begin{array}{c}-25.11 * * * \\
(4.408)\end{array}$ & $\begin{array}{c}-2.66 \\
(5.862)\end{array}$ & $\begin{array}{c}48.50 * \star * \\
(13.23)\end{array}$ \\
\hline $\mathrm{H} 1$ & $\operatorname{LnRD}_{\text {INTRA }}$ & - & - & - & $\begin{array}{c}0.629 * * * \\
(0.179)\end{array}$ & $\begin{array}{c}0.425 * \star \\
(0.201)\end{array}$ & $\begin{array}{l}-0.515 \\
(0.353)\end{array}$ \\
\hline $\mathrm{H} 2$ & $\operatorname{LnRD} D_{\text {EXTRA }}$ & - & $\longrightarrow$ & 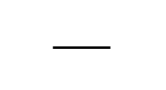 & $\begin{array}{c}-1.345^{\star * *} \\
(0.348)\end{array}$ & $\begin{array}{l}-0.530 \\
(0.487)\end{array}$ & $\begin{array}{c}1.221 \\
(0.753)\end{array}$ \\
\hline H3 & QI & - & - & - & $\begin{array}{l}-0.307 \\
(0.261)\end{array}$ & $\begin{array}{l}-0.046 \\
(0.271)\end{array}$ & $\begin{array}{l}-0.013 \\
(0.458)\end{array}$ \\
\hline $\mathrm{H} 4.1$ & $\mathrm{SC}_{\text {AERO }}$ & 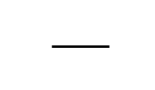 & $\longrightarrow$ & - & $0.138(0.309)$ & $\begin{array}{c}0.226 \\
(0.236)\end{array}$ & $\begin{array}{l}-0.593 \\
(0.566)\end{array}$ \\
\hline $\mathrm{H} 4.2$ & $\mathrm{SC}_{\text {EXTRA }}$ & $\longrightarrow$ & 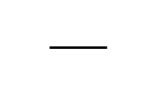 & & $\begin{array}{c}1.843 * \star \star \\
(0.507)\end{array}$ & $\begin{array}{c}0.040 \\
(0.658)\end{array}$ & $\begin{array}{c}-2.616 * \star \\
(1.165)\end{array}$ \\
\hline H5 & LnMR\&D & - & - & - & $\begin{array}{l}-0.029 \\
(0.092)\end{array}$ & $\begin{array}{l}-0.083 \\
(0.084)\end{array}$ & $\begin{array}{l}-0.115 \\
(0.179)\end{array}$ \\
\hline $\mathrm{H} 6$ & MP & $\longrightarrow$ & - & - & $\begin{array}{l}-0.360 \\
(0.557)\end{array}$ & $\begin{array}{l}-0.156 \\
(0.512)\end{array}$ & $\begin{array}{l}-0.338 \\
(0.934)\end{array}$ \\
\hline 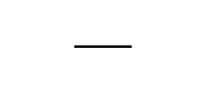 & Geopol & $\begin{array}{c}1.703 * \star \star \\
(0.450)\end{array}$ & $\begin{array}{c}1.172 * \star * \\
(0.438)\end{array}$ & $\begin{array}{c}-2.241 * * * \\
(0.699)\end{array}$ & $\begin{array}{c}1.318 * \star \star \\
(0.454)\end{array}$ & $\begin{array}{l}0.834^{*} \\
(0.470)\end{array}$ & $\begin{array}{c}-2.634 * * * \\
(1.077)\end{array}$ \\
\hline & $\mathrm{RD}_{\text {INTENSITY }}$ & $\begin{array}{c}0.315 * \star * \\
(0.079)\end{array}$ & $\begin{array}{c}0.278 * * \star \\
(0.092)\end{array}$ & $\begin{array}{l}-0.034 \\
(0.127)\end{array}$ & $\begin{array}{c}0.528 * \star * \\
(0.076)\end{array}$ & $\begin{array}{c}0.327 * * * \\
(0.098)\end{array}$ & $\begin{array}{c}-0.377 * \star \\
(0.206)\end{array}$ \\
\hline & Size & $\begin{array}{c}0.572 \\
(0.413)\end{array}$ & $\begin{array}{l}-0.349 \\
(0.452)\end{array}$ & $\begin{array}{c}-4.748 * * * \\
(1.608)\end{array}$ & $\begin{array}{c}1.449 * * * \\
(0.397)\end{array}$ & $\begin{array}{l}-0.001 \\
(0.505)\end{array}$ & $\begin{array}{c}-4.581 * * * \\
(1.737)\end{array}$ \\
\hline- & Ln_TC & $\begin{array}{c}0.091 \\
(0.240)\end{array}$ & $\begin{array}{c}0.645 \\
(0.260)\end{array}$ & $\begin{array}{c}3.225 * \star \\
(1.254)\end{array}$ & $\begin{array}{c}0.145 \\
(0.226)\end{array}$ & $\begin{array}{c}0.649 * * \\
(0.262)\end{array}$ & $\begin{array}{c}2.257 \\
(1.388)\end{array}$ \\
\hline Observations & - & 159 & 159 & 159 & 159 & 159 & 159 \\
\hline Pseudo $r$ & - & 0.0508 & 0.0981 & - & 0.1347 & 0.1979 & - \\
\hline logLik: & - & -299.880 & -284.943 & - & -273.351 & -253.402 & - \\
\hline $\begin{array}{l}\text { Over Disper- } \\
\text { sion test }\end{array}$ & - & $2.172 * *$ & - & & $2.688 * * *$ & - & 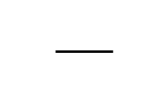 \\
\hline \multirow{2}{*}{ Vuong Test } & $\begin{array}{c}\text { P-value AIC } \\
\text { Corrected }\end{array}$ & - & 0.0166 & $\longrightarrow$ & - & 0.1488 & - \\
\hline & $\begin{array}{c}\text { P-value BIC } \\
\text { Corrected }\end{array}$ & 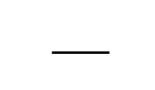 & 0.3138 & ـ & - & 0.0859 & - \\
\hline
\end{tabular}

Source: Authors.

sign (positive) and a strong significance. Furthermore, comparison between the log-likelihood tests on the four models indicates a notable increase with respect to the base model, with an increase of $\Delta 54.76$ and $\Delta 76.99$ respectively between models 5 and 7, and 6 and 8 . This rising trend is also seen in the pseudo-r parameter.

In relation to the first set of hypotheses, models 7 and 8 show a significant and positive importance of $\mathrm{H} 1$ as expected, that is, the combination and appropriation of knowledge is sensitive to aerospace R\&D expenditure in the $\mathrm{HC}$. $\mathrm{H} 2$ was rejected in model 7 and weakly significant in the binary section of model 8 , in this case, 
Table 4. TIERs' estimation.

\begin{tabular}{|c|c|c|c|c|c|c|c|}
\hline Hypothesis & Variable & NB (5) & ZINB (6) & ZINB (6) & NB (7) & ZINB (8) & ZINB (8) \\
\hline & (Intercept) & $\begin{array}{c}-2.677 * \star \\
(1.217)\end{array}$ & $\begin{array}{l}-1.503 \\
(1.176)\end{array}$ & $\begin{array}{c}3.068 * \star \\
(1.520)\end{array}$ & $\begin{array}{c}-15.3 * \star \star \\
(2.137)\end{array}$ & $\begin{array}{l}-4.066 \\
(2.839)\end{array}$ & $\begin{array}{c}18.33^{* * *} \\
(3.90)\end{array}$ \\
\hline $\mathrm{H} 1$ & LnRDINTRA & - & - & - & $\begin{array}{c}0.377 * \star \star \\
(0.083)\end{array}$ & $\begin{array}{c}0.382 * * * \\
(0.103)\end{array}$ & $\begin{array}{l}-0.133 \\
(0.115)\end{array}$ \\
\hline $\mathrm{H} 2$ & LnRDEXTRA & - & - & - & $\begin{array}{l}-0.234 \\
(0.219)\end{array}$ & $\begin{array}{l}-0.389 \\
(0.386)\end{array}$ & $\begin{array}{l}-0.377 * \\
(0.363)\end{array}$ \\
\hline H3 & QI & $\longrightarrow$ & - & - & $\begin{array}{c}0.925 * \star \star \\
(0.201)\end{array}$ & $\begin{array}{c}0.152 \\
(0.270)\end{array}$ & $\begin{array}{c}-1.315^{\star \star *} \\
(0.331)\end{array}$ \\
\hline $\mathrm{H} 4.1$ & SCAERO & - & - & - & $\begin{array}{c}0.138 \\
(0.204)\end{array}$ & $\begin{array}{c}0.067 \\
(0.225)\end{array}$ & $\begin{array}{l}-0.488 * \\
(0.280)\end{array}$ \\
\hline $\mathrm{H} 4.2$ & ScEXTRA & - & 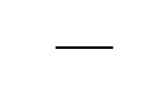 & 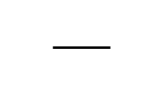 & $\begin{array}{c}0.636 * * \\
(0.293)\end{array}$ & $\begin{array}{c}0.026 \\
(0.430)\end{array}$ & $\begin{array}{l}-0.512 \\
(0.450)\end{array}$ \\
\hline $\mathrm{H} 5$ & LnMR\&D & - & 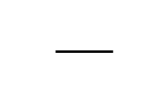 & 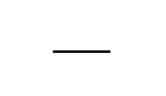 & $\begin{array}{c}-0.053 \\
(0.049)\end{array}$ & $\begin{array}{c}-0.072 \\
(0.069)\end{array}$ & $\begin{array}{l}-0.006 \\
(0.086)\end{array}$ \\
\hline $\mathrm{H} 6$ & MP & - & 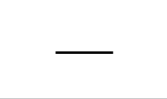 & 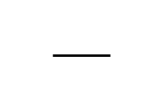 & $\begin{array}{c}-0.181 \\
(0.357)\end{array}$ & $\begin{array}{c}-0.215 \\
(0.465)\end{array}$ & $\begin{array}{l}-0.515 \\
(0.522)\end{array}$ \\
\hline$\longrightarrow$ & Geopol & $\begin{array}{c}1.430 * \star * \\
(0.256)\end{array}$ & $\begin{array}{l}0.497 * \\
(0.272)\end{array}$ & $\begin{array}{c}-2.055^{* * *} \\
(0.409)\end{array}$ & $\begin{array}{c}0.231 \\
(0.307)\end{array}$ & $\begin{array}{l}-0.036 \\
(0.351)\end{array}$ & $\begin{array}{l}-0.588 * \\
(0.467)\end{array}$ \\
\hline 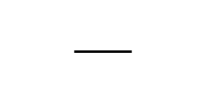 & $\begin{array}{l}\text { RDINTEN- } \\
\text { SITY }\end{array}$ & $\begin{array}{c}0.017 \\
(0.062)\end{array}$ & $\begin{array}{c}0.048 \\
(0.063)\end{array}$ & $\begin{array}{c}0.010 \\
(0.076)\end{array}$ & $\begin{array}{c}0.027 \\
(0.059)\end{array}$ & $\begin{array}{c}0.019 \\
(0.059)\end{array}$ & $\begin{array}{c}0.030 \\
(0.081)\end{array}$ \\
\hline 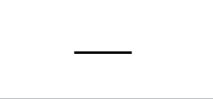 & Size & $\begin{array}{l}-0.081 \\
(0.163)\end{array}$ & $\begin{array}{c}0.129 \\
(0.182)\end{array}$ & $\begin{array}{c}0.036 \\
(0.209)\end{array}$ & $\begin{array}{c}0.239 \\
(0.149)\end{array}$ & $\begin{array}{c}0.213 \\
(0.186)\end{array}$ & $\begin{array}{l}-0.181 \\
(0.230)\end{array}$ \\
\hline 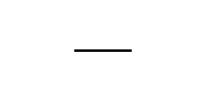 & Ln_TC & $\begin{array}{c}0.757 * * * \\
(0.086)\end{array}$ & $\begin{array}{c}0.409 * * * \\
(0.135)\end{array}$ & $\begin{array}{c}-0.456 * * * \\
(0.132)\end{array}$ & $\begin{array}{c}0.779 * * * \\
(0.085)\end{array}$ & $\begin{array}{c}0.439 * * * \\
(0.135)\end{array}$ & $\begin{array}{c}-0.565^{\star \star \star} \\
(0.142)\end{array}$ \\
\hline Observations & $\longrightarrow$ & 715 & 715 & 715 & 715 & 715 & 715 \\
\hline Pseudo $r$ & $\longrightarrow$ & 0.066 & 0.089 & - & 0.1141 & 0.1535 & - \\
\hline logLik: & - & -1128.331 & -1101.722 & - & -1071.1 & -1023.4 & $\longrightarrow$ \\
\hline $\begin{array}{l}\text { Over Disper- } \\
\text { sion test }\end{array}$ & 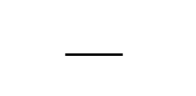 & $2.299 * * \star$ & $\longrightarrow$ & 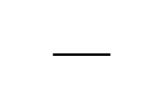 & $2.601 * \star *$ & - & - \\
\hline Vuong Test & $\begin{array}{c}\text { P-value AIC } \\
\text { Corrected }\end{array}$ & - & 0.00092 & - & - & $9.8869 e-05$ & - \\
\hline 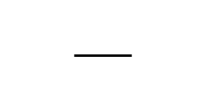 & $\begin{array}{c}\text { P-value BIC } \\
\text { Corrected }\end{array}$ & 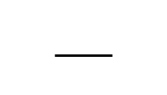 & 0.07127 & - & - & 0.19604 & - \\
\hline
\end{tabular}

Source: Authors.

the influence of $\mathrm{H} 2$ is positive as expected. The results relating to the variables that analyze the appropriation of aerospace technological knowledge from the military industry have led to $\mathrm{H} 5$ and $\mathrm{H} 6$ being rejected. Thus, as for the OEM group, R\&D investment in military activities by the $\mathrm{HC}$ does not generate a significant impact on the appropriation of aerospace knowledge for suppliers. It should also be noted that neither the size of the firm variable nor the geopolitical relationship nor the R\&D intensity between the home country and the HC were significant in models 7 and 8 . The TC variable, on the contrary, is very significant and positive. 
Finally, the overdispersion tests (Cameron and Trivedi, 1990) between models 1 and 3, and 5 and 7 were significant and therefore suggested the use of the binomial negative model to the detriment of the Poisson model. Moreover, the Vuong test has also been applied, with the result that ZINB models 2, 4, 6 and 8 represent an improvement over NB models 1, 3, 5 and 7. The log-likelihood parameters of each model allow the same conclusion to be reached.

\section{DISCUSSION}

The technological collaboration is shown to be qualitatively and quantitatively different between the sets of OEM plants and the Tier 1 suppliers, as the former have participated in substantially fewer international technological collaborations than the latter. From this perspective, it can be affirmed that the set of Tier 1 firms have greater capacity to establish technological alliances with HC firms than the OEMs. This is a novelty with respect to the previous strategy of firms in this industry, and can be explained by the increasing participation of tier firms in the aerospace knowledge creation process due to the mentioned OEMs' R\&D risk sharing and outsourcing strategy, and the great development of specific subsystems in related industries like UAVs (Unmanned aerial vehicle), cybersecurity, or ATM (Air Traffic Management) for example.

The results of this research are based on a sample that includes a large number of countries, which makes it more representative than most previous studies, focused on a single country. On the other hand, studying the firms in the sample separately, according to their position in the hierarchy of AI organization (OEMs and TIER firms) seems quite appropriate, since most of TIER firm are not entirely dedicated to aerospace industry but to other related industries as well. Besides, as mentioned above, aerospace firms' tasks are clearly delimited, especially those carried out by OEM and TIER, thus it was supposed to show a different pattern of knowledge production and appropriation and this is something that results have confirmed.

This study has been able to demonstrate that there are HC factors that favor knowledge creation in firms, which is the main contribution of this research. Thus, although the OEM and TIER groups are capable of appropriating knowledge spillovers from their surroundings, the OEM set is more competent in capturing these spillovers than the second group. This is explained by the fact that in the OEM set R\&D intensity is combined with the capture of aerospace spillovers from the HC, while in the TIER group the capture of aerospace spillovers from the $\mathrm{HC}$ is combined with TC. The different behavior of the OEM and tier groups is due to their different absorptive capacity (Zahra and George, 2002; Cohen and Levinthal, 1990).

In this regard, OEMs use a greater diversity of knowledge and consequently have greater TC, as they integrate knowledge from very diverse technological fields (avionics, propulsion, aerostructure manufacturing, etc.), thereby reducing the possibility of knowledge loss. The complexity of this process forces them to develop an R\&D effort of great intensity which, moreover, is favored by the fact that there is great industrial concentration in their field, which also promotes R\&D investment, since this concentration reduces the risk of knowledge loss to the public domain. Therefore, their greater absorptive capacity enables them to identify more knowledge in the $\mathrm{HC}$ and integrate it. Hence, the results of this study coincide with those of Forés and Camisón (2016) as they show that business absorptive capacity requires development of the knowledge base by means of improving internal knowledge creation capacity.

On the contrary, TIER firms use more specific and applied knowledge and, therefore, have less need to broaden their technological base. Thus their absorptive capacity depends rather on TC, that is, on the experience accumulated in their sector. Furthermore, the nature of the knowledge of this set (more specific and applied) enables it to be learnt more easily in their environment, thereby helping to discourage this group from making an effort in R\&D activities. Consequently, they have less absorptive capacity and are less capable of incorporating technological knowledge than the previous set.

The lack of significance of $\mathrm{H} 2$ in most of models contradicts the expected results. It could be supposed that an industry that is as transversal to others as aerospace could take advantage of spillovers from other technological sectors, however the results showed that this not the case, quite on the contrary it turned out to be a negative relation. One explanation for such outcome could lie in the fact that it we used the variable 
total R\&D produced in the HC, instead of R\&D of the related industries such as automotive, telecommunications, electronics, shipbuilding and medicine (Guffarth and Barber, 2013). Another possible explanation is the patent-based dependent variable. Many OEM firms do not use patents as a form of appropriability because many projects are considered "strategic" and involve confidentiality clauses, which probably prevents firm from patenting their inventions. And finally, another possible explanation to this, it could be that externalities from other sectors have an impact on OEM firms knowledge production when specialization in aerospace in those countries is high, and investment in R\&D to other sectors is low, since OEM firms need huge amount of R\&D investments, in order to carry out their risky and long term projects.

The participation of research institutions in R\&D alliances with aerospace companies is minimal. This is consistent with Mowery (2012) and Niosi and Zheghu (2005), on considering that universities do not participate in the knowledge creation process due to the nature of the aerospace sector, strongly committed to the defense of the country, and therefore wary of the publication of information, whereas universities disseminate the knowledge they create through scientific papers, conferences and patents (McAdam et al., 2008). This outcome suggests that its necessary focus more research on the possible contribution of universities knowledge spillovers to Aerospace firms.

However, although no direct relationship is produced, as seen above, there are knowledge spillovers to HC plants or the partners that firms establish such relationships with. The empirical analysis probed that spillovers affect both groups of firms. In the case of OEM firms, research institutions have an impact on firm's R\&D alliances when they produce knowledge in AI related fields, however this group do not benefit from spillovers of research institutions in the field of aerospace. The reason behind it is the higher complexity of the tasks carried out by OEMs as they need to integrate very different technologies, technologies which are not included in aerospace field, but are related to it.

On the contrary, Tier 1 firms benefit from both Research institutions spillovers in aerospace and its related industries, however the evidence of their impact is not as strong as in the OEM case, (which is confirmed by both models with a strong significance).

On the other hand, HC's research institutions influence positively TIER firms through their perceived quality, which could be interpreted as the influence that the university graduates and researchers of these institutions have by joining companies that collaborate with the Tier 1 firms or the firms themselves.

This result is consistent, on the one hand, with those of Azagra-Caro et al. (2017) who explain the case of universities that spillover knowledge through inventors who patent citing their own theses, or aerospace employees who establish academic relations with university groups. On the other hand, it is similarly consistent with the observations made by Niosi and Zheghu (2005), who affirm that knowledge spillovers in the OEM group receive codified knowledge, more inclined to the development of radical innovations (Asheim and Coenen, 2005), and by contrast. Tier 2 and 3 group of firms benefit from spillovers which usually involve tacit knowledge transfer.

Finally, we would like to add that this is one of the main contributions of our research, since to our knowledge there are few studies that support the existence of knowledge spillovers from overseas research institutions to foreign Aerospace corporations, and this conclusion could be useful for corporate managers as well as for government practitioners.

The last set of hypotheses has results that are partially consistent with the bibliography analyzed. There are numerous works and case studies that show technology transfer in a more or less veiled fashion from military research centers to civil ones (Mowery, 2012; Mian, 2011). However, R\&D programs dedicated to defense have always tried to prevent knowledge leaks through external sources, especially to foreign companies, as this could compromise national security. In this respect, the results of this study coincide in concluding that investment in R\&D does not have any impact on either OEMs or tier firms.

The explanation for this lies in the fact that governments, which have significant ability to influence the planning and organization of the military and civil branches of the AI (Braddorn and Hartley, 2007), effectively restrict knowledge loss. Moreover, the non-significance of this factor may also be explained by the fact that most of the projects that incorporate non-national suppliers are those undertaken by companies in Europe and the United States. Although there are a large number of projects in other countries, notably 
including some cutting-edge projects (Chengdu J-20 or the Sukhoi Su-57), they rarely include foreign firms among their main suppliers, probably following Ministry of Defense directives. In this way, further research is necessary to analyze the role of public policy in fostering knowledge creation and dissemination in aerospace industry at international level.

The protectionist attitude of governments manifested in the results of the preceding analysis is quite consistent with the strong positive impact of the Geopol variable. It is thus logical that if a firm's HC belongs to the same defense bloc as the home country, the probability of forming R\&D alliances with HC firms increases considerably. However, this factor only influences the OEM group, much more supervised by their government's defense policies than the tier group, which is much more internationalized and with a lesser degree of commitment to the country's defense policy and advanced technology.

The analysis of these results raises the question to what extent the spillovers that have effectively had an impact on firms are generated exclusively in civil aerospace R\&D or, on the contrary, whether these firms may in turn receive spillovers of the factors that have not resulted significant from research institutions and military projects, which would be an interesting future line of research.

This study has certain limitations that may serve to develop future lines of research. It should first be emphasized that although aerospace activity is transversal and cuts across many sectors it does not have to appropriate knowledge from all of them. In this respect, it would be interesting in future studies to analyze the spillovers from the R\&D of related sectors such as automotive, telecommunications, electronics, shipbuilding or medicine.

We have also found an interesting line of research to track in detail the connections of TIER firms with HC's research institutions, specially the possible transfer of tacit knowledge.

Likewise, investment in military R\&D could be studied over a longer period of time (10, 15 or 20 years), as some technologies can later become obsolete. Likewise, offset negotiations between countries may go a long way towards explaining the formation of technological alliances; however, the unavailability of data for the sample of plants that has been used in this study has precluded the inclusion of this factor in this research.

Also it would be very interesting to carry out further research on the role of public policy as inhibitor of knowledge spillovers or as director of national aerospace firms. Moreover, further research is also need in analyzing the role of GVC, industrial clusters and ecosystems un aerospace industry.

\section{CONCLUSION}

The aims of this research have been partially achieved, on the one hand, the split of the data set into the OEM and TIER group was justified since both groups proved to have different pattern of knowledge spillover appropriation consistent with their distinct nature. In the OEM group, knowledge appropriation is related to a strong inhouse investment in R\&D, while the in the TIER group it is rather explained by the experience of the corporation in the specific field they work in, and they are more prone to establish international technological alliances.

This study confirmed part of the hypotheses proposed although with different impacts for the OEM and TIER group. The research has confirmed the appropriation of knowledge spillovers from aerospace R\&D in the HC, the acquisition of knowledge spillovers from the HC's education and research institutions as well, both in their role as labor trainers and in their function of scientific literature production, and the appropriation of knowledge spillovers from the R\&D performed in defense has been discarded. Finally, geopolitical match between the home country and the $\mathrm{HC}$ has been proved an important factor which contributes to knowledge appropriation.

Therefore, the results of this paper suggests that firms must take HC's universities, research centres and investment in aerospace R\&D into account as source factors of knowledge spillover. Policymakers as well should plan geopolitical relations having in mind the importance of HC's Universities, research centres and corporations as a source of knowledge spillovers. 


\section{REFERENCES}

Almeida, P. \& Phene, A. (2004). Subsidiaries and knowledge creation: The influence of the MNC and host country on innovation. Strategic Management Journal, 25, 847-864. doi: https://doi.org/10.1002/smj.388

Asheim, B. T. \& Coenen, L. (2005). Knowledge bases and regional innovation systems: Comparing Nordic clusters. Research policy, 34(8), 1173-1190. doi: https://doi.org/10.1016/j.respol.2005.03.013

Audretsch, D. B. \& Feldman, M. P. (2003). Knowledge Spillovers and the Geography of Innovation. Handbook of Urban and Regional Economics, 4, 2713-2739. doi: https://doi.org/10.1016/S1574-0080(04)80018-X

Audretsch, D. B. \& Feldman, M. P. (1996). R\&D spillovers and the geography of innovation and production. The American economic review, 86(3), 630-640.

Audretsch, D. B. \& Lehmann, E. E. (2005). Does the knowledge spillover theory of entrepreneurship hold for regions? Research Policy, 34(8), 1191-1202. doi: https://doi.org/10.1016/j.respol.2005.03.012

Audretsch, D., Lehmann, E. \& Warning, S. (2004). University spillovers: Does the kind of science matter? Industry and innovation, 11(3), 193-206. doi: https://doi.org/10.1080/1366271042000265375

Azagra-Caro, J. M., Barberá-Tomás, D., Edwards-Schachter, M. \& Tur, E. M. (2017). Dynamic interactions between university-industry knowledge transfer channels: A case study of the most highly cited academic patent. Research Policy, 46(2), 463-474. doi: https://doi.org/10.1016/j.respol.2016.11.011

Boutellier, R., Gassmann, O. \& Von Zedtwitz, M. (2013). Managing global innovation: uncovering the secrets of future competitiveness. Springer Science \& Business Media.

Braddorn, D. \& Hartley, K. (2007). The competitiveness of the UK aerospace industry". Applied Economics, 39(6), 715-726. doi: https://doi.org/10.1080/00036840500448391

Broekel, T., and Boschma, R. (2011). Aviation, space or aerospace? Exploring the knowledge networks of two industries in the Netherlands. European Planning Studies, 19(7), 1205-1227. doi: https://doi.org/10.1080/09654313.2011.573133

Butterworth-Hayes, P. (2007). UK aerospace faces major skills shortage. Aerospace America, 45(2), 4-6.

Cameron, A. C. \& Trivedi, P. K. (1990). Regression-based tests for overdispersion in the Poisson model. Journal of econometrics, 46(3), 347-364. doi: https://doi.org/10.1016/0304-4076(90)90014-K

Cantwell, J. \& Piscitello, L. (2005). Recent location of foreign-owned research and development activities by large multinational corporations in the European regions: the role of spillovers and externalities. Regional Studies, 39(1), 1-16. doi: https://doi.org/10.1080/0034340052000320824

Coe, David T. \& Elthanan, Helpman (1994). International R\&D spillovers. European Economic Review, 39, 859-887. doi: https://doi.org/10.1016/0014-2921(94)00100-E

Cohen, W. M. \& Levinthal, D. A. (1990). Absorptive capacity: A new perspective on learning and innovation. Administrative science quarterly, 128-152. doi: https://doi.org/10.2307/2393553

Crabb, D. M. (1989). An investigation into the effects which aerospace industry offset trade agreements have on United States Air Force mission performance (No. AFIT/GLM/LSM/89S-11. Air force inst of tech wright-patterson afb oh school of systems and logistics)

CSO2015-67662-P (2014). Research project: Estrategia de Innovación Empresarial en España. Comportamientos Territoriales.

CSO2015-67662-P (2017). Research Project: La Brecha Digital en la Unión Europea. Modelos Explicativos, Predictivos y Espaciales.

D’Agostino, L., Laursen, K. \& Santangelo, G., (2012). The impact of R\&D offshoring on the home knowledge production of OECD investing regions. Journal of Economic Geography, 13 (1), 145-175. doi: https://doi.org/10.5465/AMBPP.2012.15692abstract

Dunning, J. H. \& Lundan, S. M. (2009). The Internationalization of Corporate R\&D: A Review of the Evidence and Some Policy Implications for Home Countries. Review of Policy Research, 26, 13-33. doi: https://doi.org/10.1111/j.15411338.2008.00367.x

ECORYS, F. (2009). Sector Competitiveness Studies-Competitiveness of the EU Aerospace Industry with focus on: Aeronautics Industry. In. European Commission, Directorate-General Enterprise \& Industry.

Eriksson, S. (2000). Technology spill-over from the aircraft industry: the case of Volvo Aero". Technovation, 20(12), $653-664$. doi: https://doi.org/10.1016/S0166-4972(00)00009-2 
Florida, R. (1996). The globalization of R\&D: results from a survey of foreign-affiliated R\&D laboratories in the USA. Research Policy 26(1), 85- 103. doi: https://doi.org/10.1016/S0048-7333(97)00004-8

Fontana, R., Geuna, A. \& Matt, M. (2006). Factors affecting university-industry R\&D projects: The importance of searching, screening and signalling. Research policy, 35(2), 309-323. Doi: https://doi.org/10.1016/j.respol.2005.12.001

Forés, B. \& Camisón, C. (2016). Does incremental and radical innovation performance depend on different types of knowledge accumulation capabilities and organizational size? Journal of Business Research, 69(2), 831-848. doi: https://doi.org/10.1016/j.jbusres.2015.07.006

Gertler, M. S. (2003). Tacit knowledge and the economic geography of context, or The undefinable tacitness of being (there). Journal of Economic Geography. 3(1), 75-99. doi: https://doi.org/10.1093/jeg/3.1.75

Griliches, Z. (1990). Patent statistics as economic indicators: a survey. (No. w3301). National Bureau of Economic Research. doi: https://doi.org/10.3386/w3301

Guffarth, D. \& Barber, M. J. (2013). The European aerospace R\&D collaboration network. (No. 84-2013). FZID Discussion Paper.

Guimon, J. (2008). Government strategies to attract R\&D-intensive FDI. OECD Global forum on International investment. doi: https://doi.org/10.1007/s10961-008-9091-1

Ha, Y. J. \& Giroud, A. (2015). Competence-creating subsidiaries and FDI technology spillovers. International Business Review, 4(10), 605-614. doi: https://doi.org/10.1016/j.ibusrev.2014.11.001

Healey, G. (1999). Defence Industry Offset Association Position on Offset Issues. Trends and Challenges in Aerospace, 216.

Hollanders H., Van Cruysen, A. \& Vertesy, D. (2008). Sectoral innovation systems in Europe: The case of the aerospace sector. Maastricht: MERIT

Jaffe, A. B., (1989). Real effects of academic research. American Economic Review 79(5), 957-970.

Jaffe, A. B., Trajtenberg, M. \& Henderson, R. (1993). Geographic localization of knowledge spillovers as evidenced by patent citations. The Quarterly journal of Economics, 108(3), 577-598. doi: https://doi.org/10.2307/2118401

Jordá-Borrell, R., Ruiz-Rodríguez, F. \& González-Relaño, R. (2015). Factors and taxonomy of technology purchase (TP) by internationalized innovative companies in peripheral European regions. Papers in Regional Science, 94, S139-S174. doi: https://doi.org/10.1111/pirs.12172

Krämer, A., Kretzschmar, M. \& Krickeberg, K. (Eds.) (2010). Modern infectious disease epidemiology: Concepts, methods, mathematical models, and public health. Springer Science \& Business Media. Doi: https://doi.org/10.1007/978-0-38793835-6

Kuemmerle, W. (1999). Direct investment in industrial research in the pharmaceutical and electronics industries - results from a survey of multinational firms. Research Policy, 28, 179-193. doi: https://doi.org/10.1016/S0048-7333(98)00110-3

Lee, Y. G., Lee, J. D., Song, Y. I. \& Lee, S. J. (2007). An in-depth empirical analysis of patent citation counts using zero-inflated count data model: The case of KIST. Scientometrics, 70(1), 27-39. doi: https://doi.org/10.1007/s11192-007-0102-Z

Liu, M., and Chen, S. (2012). MNCs' offshore R\&D networks in host country's regional innovation system: The case of Taiwan-based firms in China. Research Policy, 41, 1107-1120. doi: https://doi.org/10.1016/j.respol.2012.03.016

López, C. \& Vidal, M. (2010). External uncertainty and entry mode choice: Cultural distance, political risk and language diversity. International Business Review, 19(6), 575-588. doi: https://doi.org/10.1016/j.ibusrev.2010.03.007

Lopez-Otero, J. (2014). Geografía de los procesos de innovación del clúster aeronaútico andaluz. Revista de Estudios Andaluces, 31, 127-156. doi: https://doi.org/10.12795/rea.2014.i31.06

López-Otero, J., Cabrera-Contreras, G. \& Jordá-Borrell, R. (2015). Aplicación de un modelo de regresión a análisis de los conductos de transferencia tecnológica del cluster aeroespacial andaluz. Revista de Estudios Regionales, 103, $189-220$.

Lucendo-Monedero, A. L., Ruiz-Rodríguez, F. \& González-Relaño, R. (2019). Measuring the digital divide at regional level. A spatial analysis of the inequalities in digital development of households and individuals in Europe. Telematics and Informatics, 41, 197-217. doi: https://doi.org/10.1016/j.tele.2019.05.002

McAdam, Rodney, Tom O'Hare \& Sandra Moffett (2008). Collaborative knowledge sharing in composite new product development: an aerospace study. Technovation, 28,5, 245-256. doi: https://doi.org/10.1016/j.technovation.2007.07.003

McGuire, S. (2014). Global value chains and state support in the aircraft industry. Business and Politics, 16(4), 615-639. doi: https://doi.org/10.1515/bap-2014-0014

Mian, S. A. (Ed.). (2011). Science and Technology Based Regional Entrepreneurship: Global Experience in Policy and Program Development. Edward Elgar Publishing. doi: https://doi.org/10.4337/9780857936295 
Morschett, D., Schramm-Klein, H. \& Swoboda, B. (2010). Decades of research on market entry modes: What do we really know about external antecedents of entry mode choice? Journal of International Management, 16(1), 60-77. doi: https://doi.org/10.1016/j.intman.2009.09.002

Moser, R., Heiko, A. G. \& Gnatsy, T. (2019). The Indian aerospace industry, 1, 40-56

Mowery, D. C. (2012). Defense-related R\&D as a model for "Grand Challenges" technology policies. Research Policy, 41(10), 1703-1715. doi: https://doi.org/10.1016/j.respol.2012.03.027

Niosi, J. (2012). R\&D Support for the Aerospace Industry: A Study of Eight countries and One Region: A Report. Aerospace Review, 12, 44-59

Niosi, J., and Zhegu, M. (2005). Aerospace clusters: local or global knowledge spillovers? Industry \& Innovation, $12(1$ ), 5-29. doi: https://doi.org/10.1080/1366271042000339049

Niosi, J. \& Zhegu, M. (2010). Multinational Corporations, Value Chains and Knowledge Spillovers in the Global Aircraft Industry. Institutions and Economies, 109-141.

Nooteboom, B., Van Haverbeke, W., Duysters, G., Gilsing, V. \& Van den Oord, A. (2007). Optimal cognitive distance and absorptive capacity. Research policy, 36(7), 1016-1034. doi: https://doi.org/10.1016/j.respol.2007.04.003

Parr, W. C. (2006). China Offshoring: Wave of Future. Aviation Week and Space Technology, 164(8), 88.

Polak, C. \& Belmondo, S. (2006). Japan R\&D Policies and Programs in the Aeronautic and Space Sectors. SERIC, Japan.

PWC. (2014). The runway to growth: Using market understanding to drive efficient innovation in the aerospace, defence and security industry.

PWC. (2016). Aerospace and Defense: 2015 year in review and 2016 forecast.

Rychen, F. \& Zimmermann, J. B. (2008). Clusters in the global knowledge-based economy: knowledge gatekeepers and temporary proximity. Regional Studies, 42(6), 767-776. doi: https://doi.org/10.1080/00343400802088300

Stembridge, B. (2007). Eastward Ho!-The Geographic Drift of Global R\&D. Knowledge Link newsletter from Thomson Scientific, 2007.

Thomson, R. (2013). National scientific capacity and R\&D offshoring. Research Policy, 42, 517-528. doi: https://doi.org/10.1016/j.respol.2012.07.003

Zedtwitz, M., and Gassmann, O. (2002). Market versus technology drive in R\&D internationalization: four different patterns of managing research and development. Research policy, 31(4), 569-588. doi: https://doi.org/10.1016/S00487333(01)00125-1

Wessner, C. W. (Ed.). (1999). Trends and Challenges in Aerospace Offsets. National Academies Press.

Zahra, S. A. \& George, G. (2002). Absorptive capacity: A review, reconceptualization, and extension. Academy of management review, 27(2), 185-203. doi: https://doi.org/10.2307/4134351 
Annex 1. OEM Variables descriptives and correlation.

\begin{tabular}{|c|c|c|c|c|c|c|c|c|c|c|c|c|c|c|c|c|}
\hline & & Min & Max & SD & Ave & 1 & 2 & 3 & 4 & 5 & 6 & 7 & 8 & 9 & 10 & 11 \\
\hline 1 & Pat & 0,00 & 450,0 & 39,61 & 9,01 & & & & & & & & & & & \\
\hline 2 & LnRDINTRA & $-3,50$ & 10,11 & 2,49 & 4,54 & 0,21 & & & & & & & & & & \\
\hline 3 & LnRDEXTRA & 6,05 & 12,94 & 1,55 & 9,61 & 0,16 & 0,80 & & & & & & & & & \\
\hline 4 & LnMR\&D & $-2,08$ & 12,48 & 2,86 & 5,65 & $-0,02$ & $-0,27$ & $-0,19$ & & & & & & & & \\
\hline 5 & MP & 0,00 & 1,00 & 0,48 & 0,37 & 0,14 & 0,75 & 0,87 & $-0,24$ & & & & & & & \\
\hline 6 & QI & 2,70 & 6,30 & 0,81 & 4,97 & 0,15 & 0,74 & 0,86 & $-0,18$ & 0,86 & & & & & & \\
\hline 7 & SCAERO & 2,98 & 10,43 & 1,73 & 7,09 & 0,03 & 0,53 & 0,54 & $-0,22$ & 0,53 & 0,57 & & & & & \\
\hline 8 & ScExtra & 0,00 & 13,90 & 1,83 & 10,21 & 0,17 & 0,68 & 0,68 & $-0,22$ & 0,61 & 0,60 & 0,33 & & & & \\
\hline 9 & geopol & 0,0 & 1,0 & 0,49 & 0,40 & 0,22 & 0,19 & 0,21 & $-0,06$ & 0,19 & 0,27 & $-0,14$ & 0,12 & & & \\
\hline 10 & R.D_intensity & 0,08 & 10,36 & 3,12 & 5,46 & 0,20 & $-0,05$ & $-0,06$ & 0,10 & $-0,06$ & $-0,02$ & $-0,09$ & $-0,01$ & $-0,06$ & & \\
\hline 11 & Size & 8,12 & 11,34 & 0,89 & 9,88 & $-0,01$ & 0,01 & $-0,02$ & 0,00 & $-0,08$ & $-0,06$ & 0,11 & $-0,05$ & 0,06 & $-0,45$ & \\
\hline 12 & TC & 0,0 & 7,97 & 1,47 & 6,41 & 0,01 & $-0,15$ & $-0,14$ & 0,01 & $-0,19$ & $-0,19$ & $-0,02$ & $-0,16$ & 0,15 & $-0,25$ & 0,74 \\
\hline
\end{tabular}

Source: Authors.

Annex 2. TIER Variables descriptives and correlation.

\begin{tabular}{|c|c|c|c|c|c|c|c|c|c|c|c|c|c|c|c|c|}
\hline & & Min & Max & SD & Ave & 1 & 2 & 3 & 4 & 5 & 6 & 7 & 8 & 9 & 10 & 11 \\
\hline 1 & Pat & 0,0 & 1146 & 65,62 & 10,79 & 1,00 & 0,14 & 0,12 & 0,09 & 0,11 & 0,12 & 0,05 & 0,09 & 0,08 & 0,00 & 0,20 \\
\hline 2 & LnRDINTRA & $-3,5$ & 10,1 & 2,6 & 4,65 & 0,14 & 1,00 & 0,78 & 0,39 & 0,72 & 0,80 & 0,58 & 0,58 & 0,21 & 0,02 & $-0,11$ \\
\hline 3 & LnRDEXTRA & 2,36 & 12,9 & 1,66 & 9,57 & 0,12 & 0,78 & 1,00 & 0,45 & 0,89 & 0,92 & 0,61 & 0,64 & 0,26 & 0,03 & $-0,12$ \\
\hline 4 & LnMR\&D & $-3,0$ & 12,5 & 3,31 & 5,42 & 0,09 & 0,39 & 0,45 & 1,00 & 0,56 & 0,54 & 0,25 & 0,16 & 0,56 & $-0,01$ & $-0,13$ \\
\hline 5 & MP & 0,0 & 1,0 & 0,45 & 0,28 & 0,11 & 0,72 & 0,89 & 0,56 & 1,00 & 0,95 & 0,63 & 0,51 & 0,24 & 0,01 & $-0,12$ \\
\hline 6 & QI & 2,7 & 6,3 & 0,86 & 4,97 & 0,12 & 0,80 & 0,92 & 0,54 & 0,95 & 1,00 & 0,65 & 0,55 & 0,31 & 0,02 & $-0,13$ \\
\hline \multirow[t]{2}{*}{7} & SCAERO & 0,0 & 10,4 & 1,94 & 7,06 & 0,05 & 0,58 & 0,61 & 0,25 & 0,63 & 0,65 & 1,00 & 0,47 & $-0,05$ & 0,01 & $-0,10$ \\
\hline & ScExtra & 4,17 & 13,90 & 1,73 & 10,30 & 0,09 & 0,58 & 0,64 & 0,16 & 0,51 & 0,55 & 0,47 & 1,00 & 0,01 & 0,05 & $-0,09$ \\
\hline 8 & geopol & 0,0 & 1,0 & 0,49 & 0,4 & 0,08 & 0,21 & 0,26 & 0,56 & 0,24 & 0,31 & $-0,05$ & 0,01 & 1,00 & $-0,01$ & 0,00 \\
\hline 9 & R.D_intensity & 0,1 & 10,4 & 2,17 & 4,10 & 0,00 & 0,02 & 0,03 & $-0,01$ & 0,01 & 0,02 & 0,01 & 0,05 & $-0,01$ & 1,00 & $-0,21$ \\
\hline 10 & Size & 5,2 & 11,6 & 1,45 & 8,70 & 0,20 & $-0,11$ & $-0,12$ & $-0,13$ & $-0,12$ & $-0,13$ & $-0,10$ & $-0,09$ & 0,00 & $-0,21$ & 1,00 \\
\hline 11 & $\mathrm{TC}$ & 0,0 & 8,9 & 2,84 & 4,68 & 0,18 & $-0,12$ & $-0,11$ & $-0,10$ & $-0,11$ & $-0,11$ & $-0,11$ & $-0,10$ & $-0,02$ & $-0,03$ & 0,82 \\
\hline
\end{tabular}

Source: Authors. 